\title{
アウトラインシートを使った内容と段落構成のサポート \\ 一初級後半の作文指導実践一 \\ Support of the Contents and Paragraphs Making Use of Outline Sheet: \\ Teaching Writing at a Later Stage of Elementary Course
}

\section{木山 登茂子 \\ テンプル大学日本校}

\section{要旨}

所属機関の初級の日本語クラスには、作文活動に関連して次のような課題があった。 まず、学習者は日本語で段落を形成してまとまりのある内容を書く経験がほとんど なかった。また、カリキュラムが過密で、話寸聞く技能に重きが置かれているため、 授業時間に作文活動の時間を十分にとれなかった。

筆者は学習者の負担を増やさずに作文の内容と段落の構成をサポートすることを 目指してアウトラインシートを作成し、作文活動に活用した。具体的には、作文の原稿を 書く前作業として、アウトラインシートを使って作文の内容になる要素を書き出し、 同時に段落構成を意識するように指導した。

結果として、学習者は構成を意識してより詳しく自分のことを書くことに慣れて いったが、この実践の成果を検証する点で課題が残っている。

この実践に至る背景と実践のプロセスと成果と課題を報告する。

キーワード :

作文、初級、アウトラインシート、内容、段落構成 


\section{アウトラインシートを使った内容と段落構成のサポート \\ 一初級後半の作文指導実践一}

\section{木山 登茂子 \\ テンプル大学日本校}

\section{1. はじめに}

所属機関の日本語専攻プログラムは日本語による研究レポートの作成を最終目標と している。この目標を考えると、初級段階からレベルに合った文章表現の活動を取り 入れ、書く経験を段階的に積み重ねることが肝要だと思われる。しかし、初級の クラスのカリキュラムは過密である上、文字、語彙、文型の学習と、口頭の簡単な 言語活動が中心となっており、作文指導に十分な時間をかけることができないのが 現状である。

特に初級レベルの学習者は身近なことについて話すための語彙、文型の知識を 持っていても、まとまりのある内容を書くのに慣れていない。スピーチの教材を開発 した和泉元ほか（2005：201-202）は初級の学習者について「口頭運用の際、文を羅列 するだけで段落が形成できない、一つの話題について同じ情報を繰り返してしまう、 自分で一つの話を完結できない」と指摘しているが、この特徵が当該機関の学習者の 文章表現にも当てはまると考えられた。

このような現状と課題のある初級後半のクラスで、筆者は学習者の負担軽減を図り ながら、書く内容についてのヒントを与え、段落構成を意識させる指導を試みた。

\section{2. 先行研究}

初級後半の作文指導で学習者が原稿を書く前の過程に教師が関わる例としては、 これまで小宮（1987、1992）にあるような学習者に対する誘導質問が授業で行われ、 誘導質問を取り入れた教材（C\&P 日本語教育・教材研究会、1989）なども広く活用 されてきた。誘導質問とは、内容作りの指導段階で教師が作文の構成を考慮した配列 で質問をしていく方法のことである。小宮（1987）には、誘導質問の他に内容作りを サポートするメモの作成例、手紙の構成の指導のためのアウトラインの例などがあり、 作文執筆前の書く活動が有効であることが明らかにされている。また、小宮（1988） では読み手からの質問を利用した内容に関する推敲指導が報告されている。推詀指導 についての「書き手が本来有している記憶や思考が、読み手からの質問によって触発 され、活性化する」という指摘は本稿の実践にも参考になった。小宮（1987、1988、 1992）では誘導質問による段落構成の指導、主題文による内容の絞り込みの指導などを 成功させている。さらに、横田ほか（2009）では、言語的側面と構成的側面に重点を 置き、結束性を高める語彙、文型を明示的に示し、構成を意識しながらアウトラインを 書かせる指導の報告がある。先行研究の実践例は、授業時間内に時間をかけて作文 活動をしていることが共通している。 


\section{アウトラインシートを使った内容と段落構成のサポート \\ 一初級後半の作文指導実践一}

アウトラインに関連する教材としては、フローチャート・モデル文・テンプレートを 提示した教材（門脇・西馬 1999）が広く活用されてきた。この教材は、中・上級段階 の作文練習への移行を視野に入れ「全体に関する記述一個別の事柄 $\rightarrow$ 全体に関する コメント」などの三部構成の展開パターンを示し、「談話の展開を学習者に意識化 させることを目的にしている」（門脇 1999 ：50）。この教材のテンプレートを使う と構成を意識した文章作成が確実にできるようになっている。他方、どの作文にも この展開パターンに合わせた規定のテンプレートを利用するため、構成に変化がつけ にくく、書き手の個性を生かしにくい側面もある。

話題ごとに異なった展開を体験し、発想法と文章の構成を学べる教材としては 「作文用スターシート」（直井 2009）がある（資料 1 参照）。このテンプレートは、 マインドマップを応用して日本語母語話者の小学生の作文教育用に開発されたもので ある。中心の円に絵、あるいは言葉でテーマを書き、そこから放射状に関連する事柄 を書いていく点は一般のマインドマップと同様である。マインドマップと異なる点は、 ヒントになる問いに答えながら作文の流れに合わせて右上の枝から時計回りに記入 していくように指示され、書き手は作文のテーマとなる中心のイメージを持続させ ながら何をどのように書くかという内容の検討に集中することができる点である。 前述の誘導質問を取り入れた教材やテンプレートを提示した教材との相違点は、発想 しながら全体を俯瞰させることによって文章の構成と話の一貫性を視覚的に強調して いる点である。記入する内容は単語レベルでもよく、書く量が少なくてもよいため、 学習者の負担を最小限に抑えることができる。本実践ではこの「スターシート」を 参考に、多数の記入枠や細かい枝葉をまとめ、より単純化して大学で学ぶ初級の日本 語学習者用にアウトラインシート（3.2.4. 図 2、3 参照）を作成した。

\section{3. アウトラインシートを使った実践報告}

\section{1 実践デザインの背景}

\subsection{1 日本語プログラムの概要とカリキュラム}

本稿で報告するコースのレベルを表 1 に記す。「日本語能力試験」は当該機関の 過去の平均的な学習者の実績による。「一般的なレベル」は「使用教科書」のレベル に基づく。本稿で報告するクラスは下から 3 番目、2015 年夏学期の Japanese 2701、 Intermediate I （以下、Intermediate I ）である。 
表 1 日本語プログラムのコースとレベル

\begin{tabular}{|c|c|l|l|}
\hline $\begin{array}{c}\text { 日本語 } \\
\text { 能力試験 }\end{array}$ & $\begin{array}{c}\text { 一般的な } \\
\text { レベル }\end{array}$ & コース名、クラス名 & 使用教科書 11 \\
\hline N1、N2 & 上級 & Japanese 4002、Advanced IV & $\begin{array}{l}\text { 『時代を読み解く』2、6 章 } \\
\text { 『とびら』14、15 課 }\end{array}$ \\
\hline N2 & 中級 & Japanese 4001、Advanced III & 『とびら』9〜10、13 課 \\
\hline N2、N3 & 中級 & Japanese 3002、Advanced II & 『とびら』5〜8 課 \\
\hline N3 & 中級 & Japanese 3001、Advanced I & 『とびら』1〜4 課 \\
\hline N4 & 初級 & Japanese 2702、Intermediate II & 『げんき』19〜23 課 \\
\hline & 初級 & Japanese 2701、Intermediate I & 『げんき』13〜18 課 \\
\hline & 初級 & Japanese 1002、Elements II & 『げんき』7〜12 課 \\
\hline & 初級 & Japanese 1001、Elements I & 『げんき』1〜6 課 \\
\hline
\end{tabular}

\subsection{2 カリキュラム}

当該機関の日本語の授業は週 3 回で、Elements I 、II と Intermediate I 、II の総授業 時間は 1 コース 48 時間となっている。初級のこの 4 レベルの授業は、『初級日本語 教科書げんき I 、II 第 2 版』（2011、以下『げんき』）をメインテキストとして文型の 学習、口頭練習、読み物の読解活動を中心に進められる。

Intermediate I のコースの目標は、日常生活のためのコミュニケーション能力を高める こと、そのために必要な文法を学ぶことであり、特に話す聞く技能（oral-aural skills） に重きが置かれている。このレベルの成績配分とシラバスに記述された目標から、 作文の比重は相対的に低いと言える。さらに、このコースの特徵としては、テストが 多いことの他、宿題が多いことがあげられる。毎回教科書付属のワークブック等が 平均 3〜4 ページの割合で宿題として課される。これは復習を確実に行わせるため プログラムで定められている。

\subsection{3 初級前半の作文}

まとまった内容の作文を書く活動は Elements II から始まる。作文活動は 3 回あり、 「休日」、「日記」、「友だち募集」について 400 字程度の長さで書くことが求められる。 事前に作文の内容についての説明が授業で行われ、学習者は宿題として書く。学習し た漢字と文法事項を使うこと、「日記」「友だち募集」は教科書の中のモデル文を参考 にすることが指示される。

1 教科書の正式名、著者、出版社は参考文献の岡 (2009)、坂野ほか (2011)、宮原 (2012) を参照。 学習した課は 2015 年当時のもの。 


\subsubsection{Intermediate I (=初級後半) の学習者}

当該機関には英語圈出身の学習者が多いが、その言語環境は多様である。入学前の 日本在住歴の長いケース、他機関での日本語学習経験があるケース、配偶者が日本人 であるケース、両親のうち一方が日本人であるケースもある。

本稿で報告する 2015 年夏学期の Intermediate I の学習者は 18 名で、国籍はアメリカ 11 名、オーストリア 2 名、アメリカと日本 1 名（2 国籍）、日本 1 名、韓国 1 名、 台湾 1 名、タイ 1 名である。

\section{2 実践の内容}

\section{2.1 作文活動の目標}

初級レベルの産出活動は、語彙や文法力に制限があり自分に関すること、身近な 話題を取り上げることになる。しかし、だからこそ、目標言語を使って行う自己表現 のおもしろさと達成感が味わえる時期だと筆者は考える。書くことは「自分との対話」 （国際交流基金、2010：5）であり、筆者は初級レベルから目標言語で自分と対話し テーマについて掘り下げる体験をしてほしいと考えている。

作文は他の課題に比べ労力がかかり、また、苦手意識を持つ学習者も多い。その ために筆者は可能な限り負担を減らし達成感を得られるような工夫をして、学習者の 動機を高めたいと思っている。「2. 先行研究」で述べた小宮（1987、1988、1992）、 横田（2009）では原稿を書き始める前に授業時間内に時間をかけて準備活動を行って いたが、本稿の実践では、授業で作文に充てられる時間がカリキュラム上わずかで あるため、授業時間をあまり使わなくても可能で、学習者が取り組みやすいサポート 法を考える必要があった。そこで本実践では事前に提出するアウトラインの書かせ方 を工夫することにより作文活動をサポートしたいと考えた。初級の学習者の問題点と して国際交流基金（2000：16）に述べられているように「何を、どう書いていいのか わからない」学習者がいると予想された。

以上のことを勘案し、筆者は初級段階の作文活動の目標を次のように定めた。

1）自己表現のおもしろさを実感する。

2）段落構成を意識して文章を書けるようになる。

3）書くことに慣れて、自信を持つ。

この目標を達成するために教材作成において次の観点を重視した。

1’）身近なこと、経験などを思い出すヒントを与える。

2’）思考の展開をサポートする。

3’）作文に必要な型と内容の例を提示する。

さらに筆者は初級段階で段落構成を意識して文章を書くためには、次の二点が重要 であると考える。 
(1)テーマから逸れずに一貫性を保って書き続ける。

(2)時間軸に沿って、あるいは内容の塊で順序立てて展開する。

これをサポートするために視覚的に全体の俯瞰と構成を意識させる前述の「作文 スターシート」(直井 2009)のテンプレートを参考にした。本稿のアウトラインシート は枠外のヒントになる言葉で書く内容の発想をサポートしながら展開パターンに着目 させるものである。このアウトラインシートは、身の回りの出来事について思い出し ながらより詳しく書く説明文、場面の描写文、感想文、時間軸に沿って書く物語文 などの初級の作文活動に適していると考える。

\section{2.2 作文活動の概要}

Intermediate I になると、指定文字数が 600 字になる。2015 年夏学期にコースとして 定められていた授業の進度と作文課題は表 2 の通りである。

\subsection{3 授業の進め方と教材の使用法}

3 回の作文活動はそれぞれ図 1 の流れに沿って進めた。図 1 の一連の活動の後、 作文を書き直して再提出すると、学習者は加点が得られ作文の成績に反映される。 一回目の作文活動「おもしろい経験」のときは、アウトラインシートの書き方の説明 を行った。アウトラインシートについては、教科書のモデル文の内容を使い、一つの 枠が一段落に対応することと、時計回りに展開していくことを示し、その記入例も 示した。アウトラインシートは単語レベルでも、文で記入してもよいこと、展開を 自分で変えてもよいこととした。作文を書き始める前に構成を考えることの重要性を 強調した。「クラスでシェア」の活動はお互いの内容に関心を持ち、クラスメートから テーマの選択などのアイディアを聞き、次の作文を書く意欲を高める目的で行った。

\section{表 22015 年夏学期 Intermediate I の進度と作文課題}

\begin{tabular}{|l|l|l|l|}
\hline 週 & 『げんき』 & 作文課題（宿題） & 作文課題のモデル文と出現課 \\
\hline 1 & 13 課 & & \\
\hline 2 & $13 、 14$ 課 & & \\
\hline 3 & $14 、 15$ 課 & 「おもしろい経験」アウトライン提出 & 「日本のおもしろい経験」 13 課 \\
\hline 4 & 15 課 & 「おもしろい経験」原稿提出 & \\
\hline 5 & 16 課 & 「私が好きな町」アウトライン提出 & 「私が好きな所」 15 課 \\
\hline 6 & $16 、 17$ 課 & 「私が好きな町」原稿提出 & \\
\hline 7 & $17 、 18$ 課 & 「私の大学生活」アウトライン提出 & 「橋本くんの大学生活」 18 課 \\
\hline 8 & 18 課 & 「私の大学生活」原稿提出 & \\
\hline
\end{tabular}




\section{図 1 作文活動の流れ}

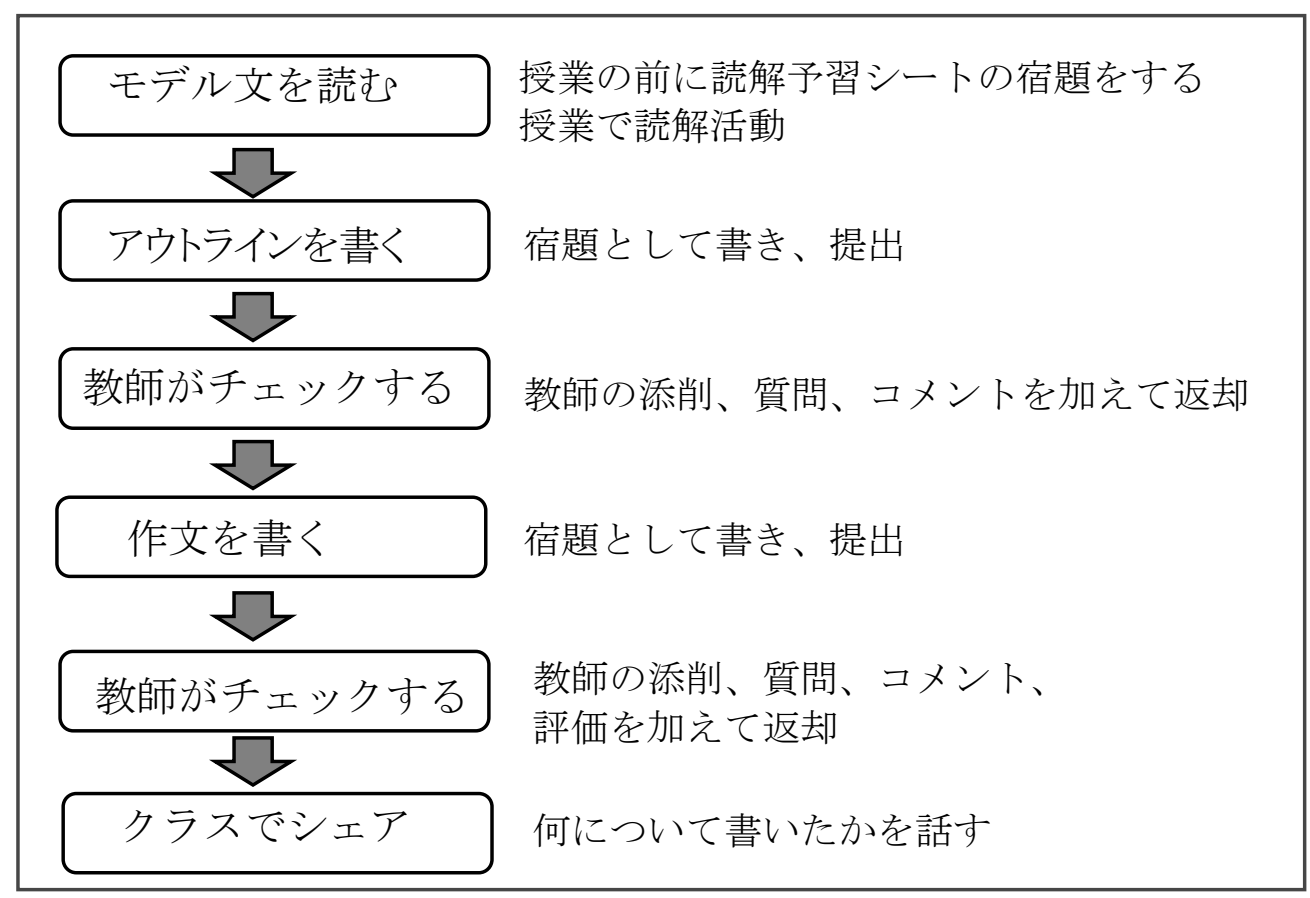

\subsection{4 結果一学習者の作文例とその分析一}

学習者の実際のアウトラインを図 2 、図 3 に、作文を表 3 、表 4 に示す ${ }^{2)}$ 。アウト ラインは手書きのものをそのまま書き写し、作文は縦書き原稿をそのまま横書きに 書き写した。

図 2 学習者Aさんのアウトライン「おもしろい経験」

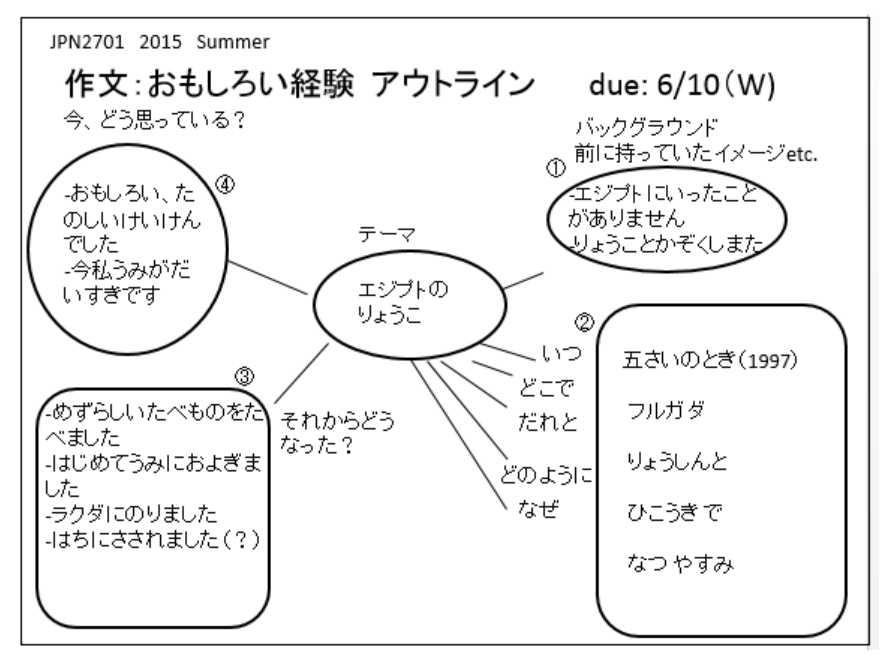

2 学習者の個人情報を守るため、表中で個人特定の手がかりとなる情報は記号○○に置き換えた。 


\section{図 3 学習者 $A$ さんのアウトライン「私の大学生活」}

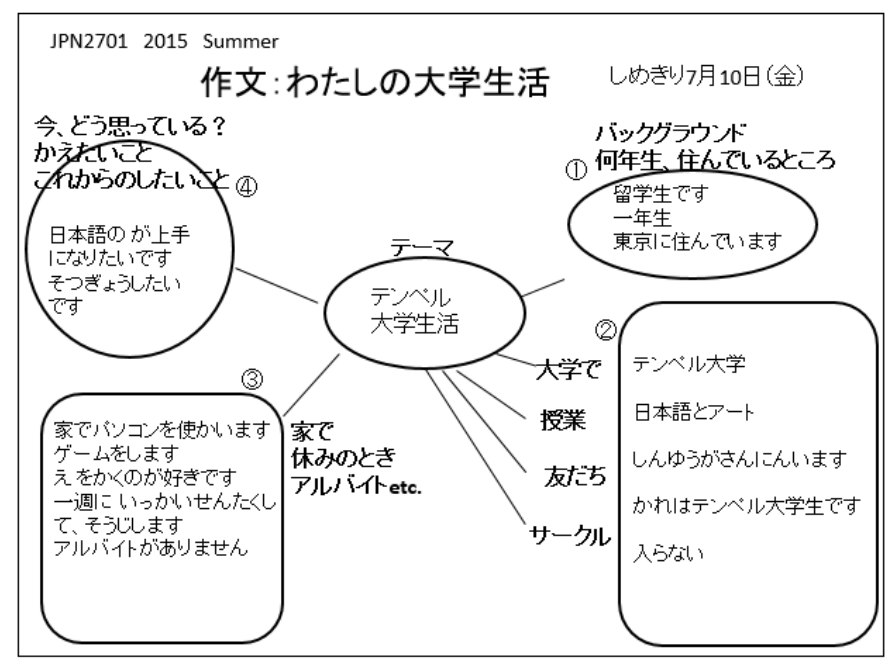

Aさんと Bさんは 2014 年夏に来日して Elements I のコースから履修している。授業 の効果による変化を見るためには、相対的に日本在住歴、日本語学習歴が短く、日本 語のレベルが当該コースに合っていて、当該コース外の日本語接触期間が比較的短い 学習者が適していると考え、分析の対象としてこの 2 人を選んだ。

「1.おもしろい経験」の作文は「経験談（物語文）」で、「2.私の大学生活」の作文は 「説明文」である。1 回目の作文でAさんは題材の選択に成功し、文法的な間違いは 散見されるものの内容的にはまとまりのある文章が書けている。アウトラインシート の利用法は、記入した言葉や短い文の中から書く内容を取捨選択し、記入した要素 から連想したことを発展させて作文に書くという方法である。しかし、1の作文の時は まだアウトラインシートの意図がよく伝わっていなかったようだ。そのため、全体が

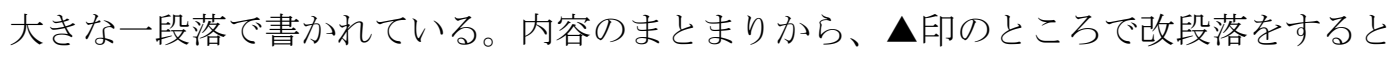
読みやすくなるが、それはちょうどアウトラインシートに記入した各記入枠のメモの まとまりに相当している。つまり、大きな流れとしてアウトラインシートの(1)(2)(3) の順に作文を書いている。ただし、(4)の記入枠に書かれた「今私うみがだいすきです」 に相当する部分は作文中下線を付したところに入っている。作文でも最後の部分に 入れていたら流れが途切れず、読み手にとって展開の予測がしやすい一貫性のある 文章になるところであったと考える。

2 の作文は、全 3 回の作文活動の最後のもので、原稿を提出したのは 1 の作文を 書いた時から 4 週間後にあたる。1 の作文と比較すると語彙や文型が増えて描写が 詳しくなり、情報量が増えている。「そうはいっても」というつなぎの言葉があり 段落の続き方に注意して書く意識がうかがえる。形式的にも段落が形成されており、 $\mathrm{A} さ ん の$ 気持ちと生活が読み手によくわかる文章になっている。文章の最後の部分は 


\section{アウトラインシートを使った内容と段落構成のサポート \\ 一初級後半の作文指導実践一}

唐突に終わっているが、Aさんはアウトラインシートの最後の(4)の記入枠に「日本語 のが上手になりたいです。卒業したいです。」という文を書いている。これを「今、 日本語が上手になりたいです。そして、卒業したいです。」などとして最終段落に 書いていたらよりまとまりのある完結した作文になっていたと考える。Aさんの二つ の作文についてアウトラインシートと作文を照合すると、作文の改善案が学習者の 考えの中から引き出せる可能性がある。

\section{表 3 Aさんの作文}

題名 : エジプトへの旅行 した。子どもの時ちょっとこわいいけいけんだたので、今ミツバチのこわいです。

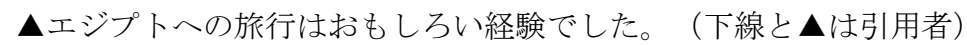
題名 : 私のテンプル大学の生活

はじめまして。わたしは○○です。現在東京でテンプル大学の大学生です。一年間 ○にすんでいて、東京の生活になれました。

私のりょうしんは旅行をするのが大好きです。まいとしあつい所にいったつもり です。ム五さいの時私ははじめてりょうしんと外海に行きました。エジプトは海や さばくがあって、きれいな所です。ピラミッドはルクソールでは有名です。二週間 フルガダでホテルにとまりました。ホテルで紅海がみえたいでした。ムはじめて海に およいで、ビーチであそびました。今まだ海が大好きんです。ホテルで水泳インスト ラクターにいました。名前はミチューです。ギリシャ人です。おもしろい人だし、 おぼえるのが上手だし、およぐのがとても上手になりました。あるひプールであそん で、はちにさされました。いたい寸ぎんでした。医者に行かなければいけませんで ○○会館にとまっています。会館はちょっとたかく、やちんは一カ月二百千円 ぐらいです。そしてついかひようがありません。とても便利ですね。 毎朝七時におきて、ちかてつに乗ります。○○から大学のえきまで一時間ぐらい かかります。月曜日から金曜日まで授業があります。一週間に三回日本語の授業を とっています。外国語を勉強するのはとてもたいいんだと思います。それに一か月に 四回サークルに出ています。たいていコンプューターゲームをしたりまんがの話しを します。日本語がじょうずになったんです。

そうはいっても大学生の生活は楽しいです。しんゆうが三人がいます。さいしょに 私ははずかしがりやでした。しかしたくさん友だちをつくりました。テンプル大学で かれにも会いました。幸せです。たいていしゅまつでがけるまえに、日本語の宿題 します。よく友達といざかやでお酒を飲んだり映画館に行きます。映画を見ながら、 ポップコーンを食べます。家で休みの時本を読んで、えをかくのが好きです。 


\section{表 4 Bさんの作文}

題名 : アメリカ道路の旅

子供の時から、私はいつも旅行がしたかったんです。休日の時いつも遠く場所に行き たかったです。私のお父さんはカナダに住んでいて、と私のお母さんはアメリカに住んで いたので、よくカナダとアメリカを旅行しました。私はいつも家族と旅行したけど、自分で ました。八日目にソルトレイクシティに行きました。私たちは彼女のお父さんと会って、 お寺に行きました。十日目に北森林に行きました。家族と会って、パーティーをしました。
いっしょにストーリーを話しました。十二日間後で州りました。私は彼女といっしょに
たくさんのことがありました。
今日も旅行が大好きです。それだので、日本に来ました。私の未来の夢は世界を旅行
するのです。アメリカに帰るの時にカナタととメリカをもう一度旅行したいです。そして、 お寺に行きました。十日目に北森林に行きました。家族と会って、パーティーをしました。
いっしょにストーリーを話しました。十二日間後で帰りました。私は彼女といっしょに
たくさんのことがありました。
今日も旅行が大好きです。それだので、日本に来ました。私の未来の夢は世界を旅行
するのです。アメリカに帰るの時にカナタととアメリカをもう一度旅行したいです。そして、 お寺に行きました。十日目に北森林に行きました。家族と会って、パーティーをしました。
いっしょにストーリーを話しました。十二日間後で帰りました。私は彼女といっしょに
たくさんのことがありました。
今日も旅行が大好きです。それだので、日本に来ました。私の未来の夢は世界を旅行
するのです。アメリカに帰るの時にカナタととアメリカをもう一度旅行したいです。そして、 お寺に行きました。十日目に北森林に行きました。家族と会って、パーティーをしました。
いっしょにストーリーを話しました。十二日間後で州りました。私は彼女といっしょに
たくさんのことがありました。
今日も旅行が大好きです。それだので、日本に来ました。私の未来の夢は世界を旅行
寸るのです。アメリカに帰るの時にカナダとアメリカをもう一度旅行したいです。そして、 お寺に行きました。十日目に北森林に行きました。家族と会って、パーティーをしました。
いっしょにストーリーを話しました。十二日間後で帰りました。私は彼女といっしょに
たくさんのことがありました。
今日も旅行が大好きです。それだので、日本に来ました。私の未来の夢は世界を旅行
するのです。アメリカに帰るの時にカナタととアメリカをもう一度旅行したいです。そして、 いつか日本も旅行したいです。

題名 : 日本の留学

子供の時からいっも日本に来たかったです。私の子供の時の親友は日本人です。彼は いつも日本について話していました。そして、毎夏日本に行きました。高校の卒業の後で 何になりたいを知りませんでした。それで、「日本で英語先生はいいしごとだ」と思い ました。2014 年 5 月 15 日に日本に引っ越して、大学を始めました。

私 5 月から 8 月まで日本人のお宅に住んでいました。そして、8 月に川崎で自分のアパートに の引っ越しました。それから、私の大学生活はちょっと忙しくなりました。私の専門は日本語 だので、毎日日本語を勉強しています。今、文法と会話と漢字の授業があります。時々大学 で友達を会います。ゲームのサークルに入りました。

生 毎日大学を終わったから、アルバイトもします。英語学校で英語先生です。月曜日から 金曜日まで 9 時ぐらい家を出て、21 時ぐらい帰ります。週末に友達とカラオケに行きます。 時々渋谷か秋葉原に買い物しに行きます。日曜日勉強もします。私の大学の生活は忙しい と思っています。休みの時東京を出たいです。山の中に行きたいです。休んだら、「いい 休みだ」と思います。

卒業の後で鎌倉市で中学校の先生になりたいです。JET プログラムもしたいです。北海道 に行きたいです。卒業の後色々なしたいことがあります。 


\section{アウトラインシートを使った内容と段落構成のサポート \\ 一初級後半の作文指導実践一}

Bさんは最初の 1 の作文の時から内容のまとまりを意識して段落を作って書くこと ができ、高校卒業後の初めての自動車冒険旅行の期待と充実した様子が書けている。 段落ごとに見てみると、出発前の旅行のきっかけや期待は詳しく書かれているが、 作文の中心となる旅行については時系列に事実が淡々と記述されており、この旅行に

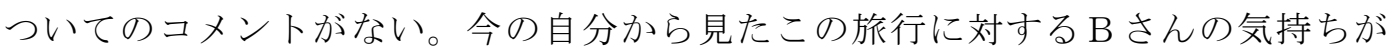
書かれていれば、この作文はもっとよくなると思われる。Bさんのアウトライン シートを見ると、(4)の記入枠が空欄になっている。文章を書き始める前に全体の構成を 考えていたら、バランスのとれた構成と内容の配置ができていたのではないだろうか。

Bさんの 2 の作文は、段落の構成もよく、日本に来た理由、今の生活、今大切に 思っていること、将来の夢がバランスよく語られている。アウトラインシートを見る と、内容は詳しくはないが 1 の作文と異なり記入枠は埋められており、文章を書き 始める前に全体像を考えていたことがうかがえる。そして、2 の作文は段落間の関係 も明確になり、作文の中心である今の生活が詳しく書かれている。

2 の作文「私の大学生活」の課題を出したときはアウトラインシートを図 3 のもの と、当該コースでこれまで使用されてきたテンプレートのアウトラインシートの 2 種類を用意し、使いやすいほうを選んで使うように指示した。従来から使用されて きたアウトラインシートは、用紙を三分割して Introduction、Body、Conclusion の 3 つ の枠で構成され、Introduction の部分に write statements that briefly express the content/theme of your composition、Body の部分に concretely write about what you discuss in the introduction section by giving examples, reasons, explanations, etc. という指示が付されて いる。18名のうち 3 名の学習者がこの従来版を選んだ。このうち 2 名は短期留学生で、 在籍するアメリカの大学の自分の専攻と将来の進路について書き、残りの 1 名は アルバイトや子育てをしながらの学生生活について書いていた。三部構成のパターン に慣れている学習者にはこのようなタイプのテンプレートが適していたと思われる。

作文を書く経験を重ねた後は学習者の自由度を上げていく調整が必要になるだろう。

\section{2.5 学習者アンケートの回答}

学期の終わりに行った授業に関するアンケートの中に図40ようなアウトラインシート に関する評価とコメントを求める項目を入れた。11 名からの回答を得たがそのうち、 「役に立つ」（中心点より左側にマーク）が 8 名、「どちらでもない」（中心点上に マーク）が 1 名、役に立たない」（中心点より右側にマーク）が 2 名だった。コメント を表 5 にまとめる。 
図 4 学習者へのアンケート

Outline sheets for Sakubun(作文) (Please rate your feeling by writing circle on the line. ) \begin{tabular}{l|l|l|l|l|l}
$100 \%$ useful & $0 \%$
\end{tabular}

(Please describe how useful, if possible.)

\section{表 5 アウトラインシートに対する学習者のコメント}

コメント -:役に立たなかった + : 役に立つた

-Good to think of the outline beforehand but it's an extra work for me.

-Not that useful. An extra explanation of the topic would be enough for me.

+ I thought it was helpful because I used it as a first draft.

+It helped me to organize my Sakubun better.

+Gave me a topic and a place to start forming my ideas.

+The outlines helps me figure out what should be in my Sakubun.

+It is very useful because it allowed us to structure the essay step by step and teacher can check the sentences written.

「役に立たない」とする 2 名のコメントを見ると、宿題が増えて負担になったと 感じたようである。何をどのように書き始め、どのように展開していったらよいか わからない学習者には内容の選択を助け、展開を示すことができたことがうかがえる。

\section{4. 実践の成果}

本稿の実践では、「3.2.1. 作文活動の目標」に述べた目標を目指し、作文の前作業 としてアウトラインシートに作文の内容を記入する宿題を課すことによって学習者の 書くプロセスに関与した。具体的には、アウトラインシートでヒントになる言葉を 与えることにより作文の内容になる要素を書き出させ、記入枠により段落を意識させ、 教師の添削やコメントを加えることによってサポートを行った。

学習者の文章表現力の急な向上を望むことは難しいが、今回の試みでは大きな流れ として学習者は構成を意識して書くことを経験し、書くプロセスで自分の考えを深め、 より詳しく自分のことを表現できるようになってきた。アウトラインシートは「2.2.4 結果一学習者の作文例とその分析一」や「2.2.5 学習者アンケートの回答」で見てきた ようにまとまりのある内容を書くために学習者のサポートになったと考える。「2.2.1 作文活動の目標」で述べた目標のうち 2）は達成できたと思われる。1）3）は現段階 では成果を客観的に検証することができていない。アウトラインシートの第一の目的 


\section{アウトラインシートを使った内容と段落構成のサポート \\ 一初級後半の作文指導実践一}

は、ヒントになる言葉で発想を引き出しながら、段落構成を意識させることであった が、ヒントの言葉や構成を意識させる記入枠の数はテーマによって変える必要がある。 文章を書く前に全体像を描くことに慣れたら、次のステップとして学習者が自分で 内容を考えアウトラインを書けるように、つまり、段落構成が自力でできるような 指導をしたい。このアウトラインシートを使った活動を繰り返すことによって 伸ばせると考える能力は、内容を膨らませる方法をつかみ、段落を意識して書く力だ と言える。

自分について書く作文は、実用性が低く、また、大学の研究レポートとは質が 異なるものだが、内容の一貫性を保つこと、構成を考えることは研究レポートに 役立つ観点である。また、自分についてまとまった内容を表現する経験は中上級 レベルに進んでいくためにも役立つだろう。

\section{5. おわりに一今後の課題一}

アウトラインを書く段階の重要性を学習者に伝える工夫がもっと必要だと感じて いる。Aさんの 2 つの作文からわかることは、このレベルの学習者に対する最終段落 の書き方のサポートの重要性である。特に、作文の結びの(4)の記入欄を意識的に活用 するように指導することが重要だろう。Bさんの 2 の作文のように、アウトライン シートを完成させ文章を書き始める前に全体像を作っておくと、バランスがとれた 一貫性のある文章が書けることを強調したいと考えている。

アウトラインシートは、カリキュラムが過密で作文指導に十分な時間をかける ことができない現状の中で、自分で内容を展開させながら一つの話を完結することが 難しい学習者に、内容をサポートして段落の構成に着目させることに役立ったと 考える。しかし、それを検証するためには、さらにアウトラインシートを使用しない 場合との比較やプロセスを見るためのプロトコル分析など、より客観的な検証が必要 であろう。

\section{謝辞}

本稿の執筆のためにご協力いただいた学習者のみなさん、とりわけ原稿の掲載を 許可してくださった方々に心からお礼を申し上げます。また、貴重なご指摘とご助言 をくださった査読委員の先生方に厚くお礼申し上げます。 


\section{参考文献}

和泉元千春・魚住悦子・熊野七絵・羽太園・三浦多佳史 (2005)「まとまりのある話をするための

教材の制作一『初級からの日本語スピーチ一国、文化、社会についてまとまった話をするために一』

制作の実践から一」『国際交流基金日本語教育紀要』1、201-216

岡まゆみ(2009)『上級へのとびらーコンテンツとマルチメディアで学ぶ日本語』くろしお出版

門脇薰(1999)「初級における作文指導－談話展開を考慮した作文教材の試み一」『日本語教育』

102、50-59

門脇薰・西馬薰(1999)『みんなの日本語初級 やさしい作文』スリーエーネットワーク

国際交流基金（2000）「授業のヒント-初級レベルの作文」『日本語教育通信』37、16-17

国際交流基金(2010)『書くことを教える』ひつじ書房

小宮千鶴子 (1987)「文章構成法による作文指導の試み一初級後半における内容作り・構成を中心

としてー」『日本語学校論集』14、69-92

小宮千鶴子 (1988)「初級の最終段階におけるプランと推敲の指導」『日本語学校論集』15、121-140 小宮千鶴子 (1992) 「日本語教育における初級段階の作文指導」『中央学院大学教養論叢』4（2）、

49-69

C\&P 日本語教育・教材研究会 (1989)『絵入り日本語作文入門一文型による短文作成からトピック別

表現練習へ一』専門教育出版

直井明子 (2009) 『最強作文術』幻冬舎

坂野永理・池田庸子・大野裕・品川恭子・渡嘉敷恭子 (2011)『初級日本語教科書げんき I ・ II

第 2 版』(The Japan Times)

宮原彬 (2012) 『留学生のための時代を読み解く上級日本語 第 2 版』スリーエーネットワーク

横田淳子・伊集院郁子（2009）「『JLC 日本語スタンダーズ』に基づいた初級段階における文章

表現指導の試み」『留学生日本語センター論集』35、87-102

資料 1 スターシート例 （直井 $2009: 93 ）$

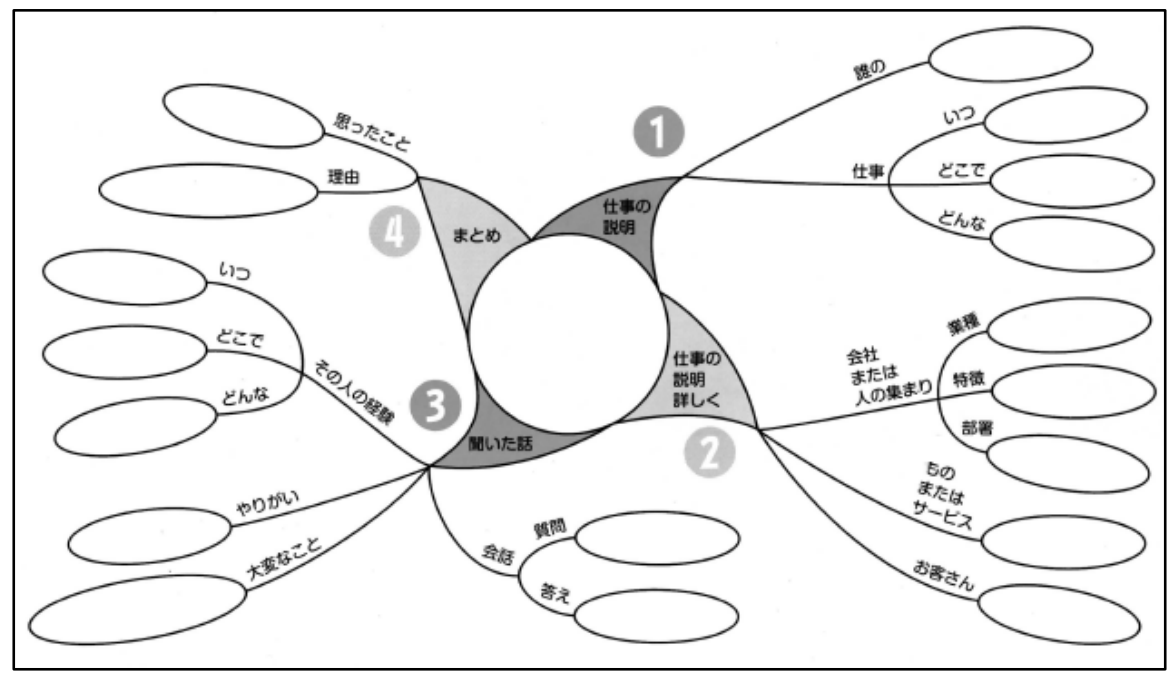

